\title{
25-0H Vitamin D Levels in Patients with Pituitary Adenoma
}

\author{
Serhat Ozcelik*1 and Mehmet Celik ${ }^{2}$ \\ ${ }^{1}$ Department of Internal Medicine, Division of Endocrinology and Metabolism, Kartal Training and Research Hospital, Turkey \\ ${ }^{2}$ Department of Internal Medicine, Division of Endocrinology and Metabolism, Antalya Kepez State Hospital, Turkey
}

*Corresponding author: Serhat Ozcelik, Department of Internal Medicine, Division of Endocrinology and Metabolism, Kartal

Training and Research Hospital, Istanbul, Turkey

\section{ARTICLE INFO \\ Received: 慧 May 06, 2019 \\ Published: May 14, 2019 \\ Citation: Serhat Ozcelik, Mehmet Celik. 25-OH Vitamin D Levels in Patients with Pituitary Adenoma. Biomed J Sci \& Tech Res 18(1)-2019. BJSTR. MS.ID.003090.}

Keywords: Pituitary Adenoma; Vitamin D; Acromegaly; Cushing Disease; Prolactinoma

\section{ABSTRACT}

Objective: Pituitary adenomas (HA) are diagnosed by radiological imaging or by evaluating the hormonal activity of the pituitary incidentaloma in order to investigate the signs and symptoms that are thought to be related to the compression of a mass in the pituitary gland. In vitamin D deficiency, the risk of osteoporosis and bone fracture increased. The aim of this study was to evaluate vitamin D levels in pituitary adenomas.

Methods: The study included 88 patients ( 60 females, 28 males) who were followed for pituitary adenoma between the years of 20016-2018. Patients' physical examination, pituitary MR results, FSH, LH, estradiol, Testosterone, ACTH, cortisol, Growth hormone, Igf1 , prolactin and $25-\mathrm{OH}$ vitamin D levels results were recorded. $1 \mathrm{mg}$ dexamethasone test was performed in appropriate patients.

Results: Of the 88 patients with pituitary adenoma, 62 (70.4\%) had vitamin D deficiency, and $19(21.6 \%)$ had vitamin D insufficiency. Only 7 patients $(8 \%)$ had vitamin D levels above $30 \mathrm{ng} / \mathrm{dl}$ and were adequate.

Conclusion: Vitamin D levels were low especially in patients with pituatare adenoma. Vitamin D deficiency should be considered and treated in these patients with high risk of osteoporosis or high risk of bone fractures when treating these patients.

\section{Introduction}

Pituitary adenomas are most common in the $3^{\text {rd }}$ decade and constitute 10 percent of all intracranial neoplasms [1-3]. Pituitary adenomas are classified according to the size and function of the cell in which they originate [4]. Functional pituitary adenomas may be disorders affecting bone metabolism. This condition has been described in cushing's disease. Vitamin D has an important clinical role due to its relationship with calcium balance and bone metabolism. This degree of vitamin D deficiency may contribute to the development of osteoporosis and the risk of fracture and fall [5]. The aim of this study was to evaluate vitamin D levels in pituitary adenomas.

\section{Materials and Methods}

The study included 88 patients (60 females, 28 males) who were followed for pituitary adenoma between the years of 20016 -
2018. Patients' physical examination, pituitary MR results, FSH, LH, estradiol, Testosterone, ACTH, cortisol, Growth hormone, Igf-1, prolactin and 25-OH vitamin D levels results were recorded. $1 \mathrm{mg}$ dexamethasone test was performed in appropriate patients

\section{Results}

Of the 88 patients with pituitary adenoma, 62 (70.4\%) had vitamin D deficiency, and 19 (21.6\%) had vitamin D insufficiency. Only 7 patients (8\%) had vitamin D levels above $30 \mathrm{ng} / \mathrm{dl}$ and were adequate. The mean age of the patients with non-functional adenoma was 41.7 years (min: 18-max: 68); 7 (33.3\%) were males and $13(61.9 \%)$ were females. In 15 patients, vit D was $<20$, while 6 patients had vit $D$ value of $\geq 20-<30$. The mean age of patients with acromegaly was 46.1 years (min: 33-max: 64); 6 (54.5\%) were males and $5(45.5 \%)$ were females. In 8 patients, vit D was $<20$, 
while 2 patients had vit $D$ value of $\geq 20-<30$. The mean age of the 3 female patients with Cushing disease was 33.3 years (min: 18-max: 48). In 2 patients, vit $\mathrm{D}$ was $<20$, while 1 patient had vit $\mathrm{D}$ value of $\geq 20-<30$. The mean age of patients with prolactinoma was 32.3 years (min: 19-max: 60); 15 (33.3\%) were males and 39 (61.9\%) were females. In 37 patients, vit D was $<20$, while 11 patients had vit $\mathrm{D}$ value of $\geq 20-<30$. Only 25 of the 88 patients had $25 \mathrm{OH}$ vitamin D levels above $30 \mathrm{ng} / \mathrm{dl}$. One of them was acromegaly, the other six patients with prolactinoma (Figure 1).

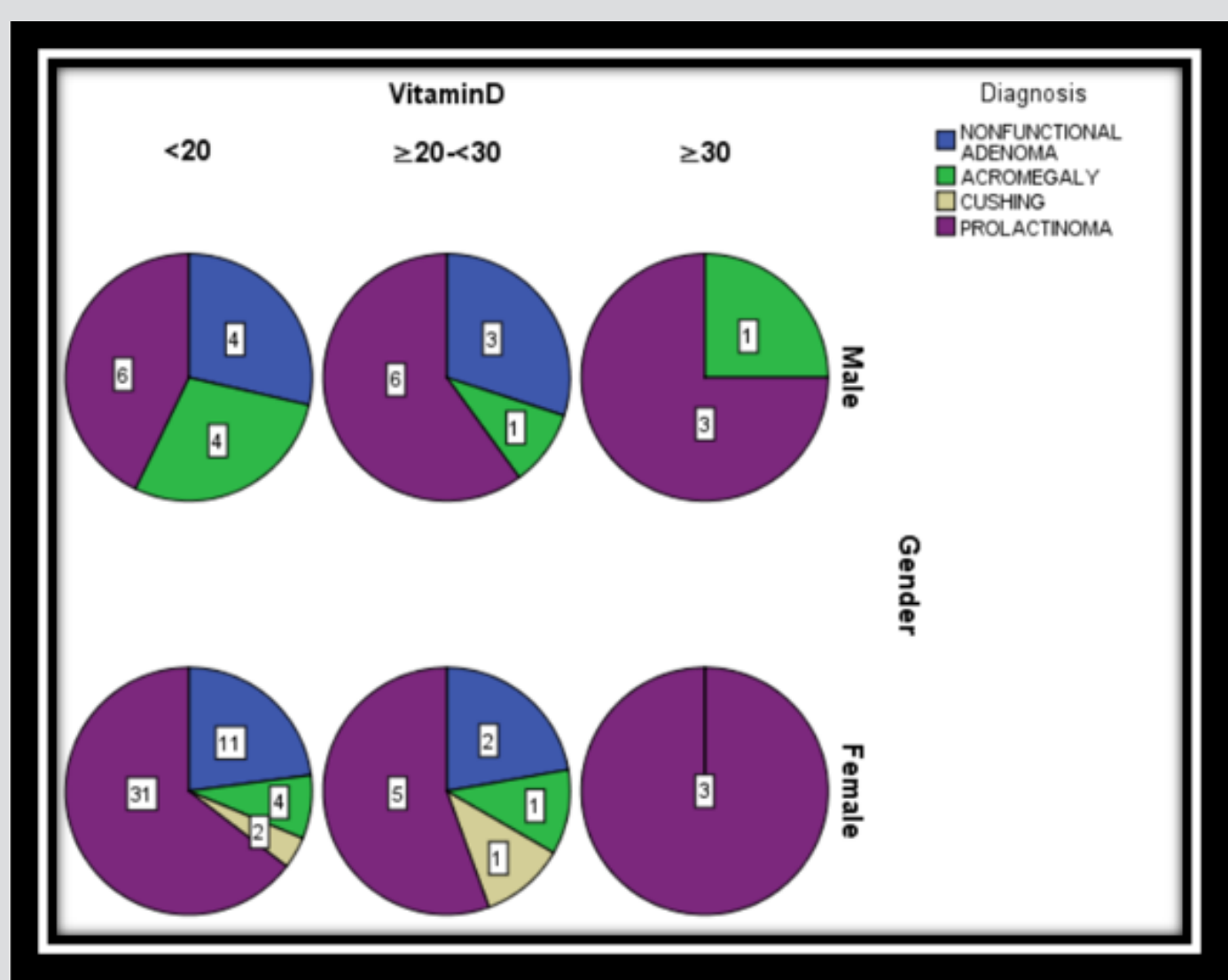

Figure 1: 25-OH vitamin D levels by gender in pituitary adenoma cases.

\section{Discussion}

Vitamin D is a secosteroid hormone. Serum 25 hydroxy $(\mathrm{OH})$ vitamin D levels are measured, and their adequacy is evaluated. ( $>30 \mathrm{ng} / \mathrm{ml}$ : adequate, $20-30 \mathrm{ng} / \mathrm{ml}$ : insufficiency, $<20 \mathrm{ng} / \mathrm{ml}$ : deficiency, $<10 \mathrm{ng} / \mathrm{ml}$ : severe deficiency) [6]. Vitamin D deficiency is associated with osteoporosis, possibly fractures and risk of falling [6,7]. Osteoblasts have prolactin (PRL) receptors. Prolactin has an adverse effect on bone metabolism by inhibiting osteoblast proliferation and increasing osteolytic activity. Prolactin also causes an increase in RANKL and osteoprotogerin. As a result, bone loss is observed. In women with prolactinoma, approximately $25 \%$ of the vertebrae are lost due to hypogonadism. Treatment with bone density increases but may not return to the old level. In men with prolactinoma, osteopenia / osteoporosis occurs due to low testosterone levels [8-12] (Table 1).

Table 1: $25-\mathrm{OH}$ vitamin D levels in patients with pituitary adenoma.

\begin{tabular}{|c|c|c|c|c|c|}
\hline \multirow{2}{*}{ Diagnosıs } & \multirow{2}{*}{ Gender } & \multicolumn{3}{|c|}{ 25-0H Vitamın D Levels(ng/ml) } & \multirow{2}{*}{ Total } \\
\hline & & $<20$ & $\geq 20-<30$ & $\geq 30$ & \\
\hline \multirow{3}{*}{ Non-Functional Adenoma } & Male & 4 & 3 & - & 7 \\
\hline & Female & 11 & 2 & - & 13 \\
\hline & Total & 15 & 5 & - & 20 \\
\hline \multirow{3}{*}{ Acromegaly } & Male & 4 & 1 & 1 & 6 \\
\hline & Female & 4 & 1 & - & 5 \\
\hline & Total & 8 & 2 & 1 & 11 \\
\hline \multirow{3}{*}{ Cushıng } & Male & - & - & - & - \\
\hline & Female & 2 & 1 & - & 3 \\
\hline & Total & 2 & 1 & - & 3 \\
\hline
\end{tabular}




\begin{tabular}{|c|c|c|c|c|c|}
\hline \multirow{2}{*}{ Prolactınoma } & Male & 6 & 6 & 3 & 15 \\
\hline & Female & 31 & 5 & 3 & 39 \\
\hline & Total & 37 & 11 & 6 & 54 \\
\hline \multirow{3}{*}{ Total } & Male & 14 & 10 & 4 & 28 \\
\hline & Female & 48 & 9 & 3 & 60 \\
\hline & Total & 62 & 19 & 7 & 88 \\
\hline
\end{tabular}

The pathogenesis of osteoporosis in patients with Cushing's disease, decreased osteoblast function, decreased calcium absorption from the bowel, calcium excretion from kidneys decreased gonadal steroid synthesis, decreased muscle mass and strength, growth hormone secretion and decreased effectIn cushing's disease, osteoporosis was found in $50 \%$ of the patients. Even in these patients, non-traumatic fractures or osteoporosis incompatible with age are detected [13-16]. In acromegalic patients, growth hormone stimulates the carboxylation of osteocalcin on the one hand and stimulates the production of RANKL and osteoprotoger. Growth hormone and IGF-1 stimulate the 1-alpha hydroxylase enzyme in the kidney to increase the synthesis of 1,25 dihydroxycholecalciferol. Even if osteoporosis does not increase in acromegalic patients, the risk of bone fracture has increased [1720]. Vitamin D deficiency and / or insufficiency were found in all patients in this study. In addition to existing pathophysiological conditions, we think that vitamin D deficiency increases the risk of osteoporosis and / or bone fracture in these patients.

\section{Conclusion}

Vitamin D deficiency should be considered and treated in these patients with high risk of osteoporosis or high risk of bone fractures when treating these patients.

\section{References}

1. Gsponer J, De Tribolet N, Déruaz JP, Janzer R, Uské A, Mirimanoff RO, et al. (1999) Diagnosis, treatment, and outcome of pituitary tumors and other abnormal intrasellar masses. Retrospective analysis of 353 patients. Medicine (Baltimore) 78(4): 236-239.

2. Saeger W, Lüdecke DK, Buchfelder M, Fahlbusch R, Quabbe HJ, et al. (2007) Pathohistological classification of pituitary tumors: 10 years of experience with the German Pituitary Tumor Registry. Eur J Endocrinol 156(2): 203-216.

3. Freda PU, Post KD (1999) Differential diagnosis of sellar masses Endocrinol Metab Clin North Am 28(1): 81-117.

4. Snyder PJ (2001) Gonadotroph adenomas. In: Endocrinology, DeGroot LJ (Ed), WB Saunders, Philadelphia.

\section{ISSN: 2574-1241}

DOI: 10.26717/BJSTR.2019.18.003090

Serhat Ozcelik. Biomed J Sci \& Tech Res

This work is licensed under Creative

Commons Attribution 4.0 License

Submission Link: https://biomedres.us/submit-manuscript.php
5. Forrest KY, Stuhldreher WL Z (2011) Prevalence and correlates of vitamin D deficiency in US adults. Nutr Res 31(1): 48-54.

6. Holick MF (2007) Vitamin D deficiency. N Engl J Med 357: 1980-1982.

7. Tsai KS, Wahner HW, Offord KP, Melton, R Kumar, et al. (1987) Effect of aging on vitamin $\mathrm{D}$ stores and bone density in women. Calcif Tissue Int 40(5): 241-243

8. Greenspan Susan L, Neer RM, Ridgway EC, Klibanski A (1986) Osteoporosis in men with hyperprolactinemic hypogonadism. Annals of internal medicine 104(6): 777-782.

9. Vartej P, Poiana C, Vartej I (2001) Effects of hyperprolactinemia on osteoporotic fracture risk in premenopausal women. Gynecol Endocrinol 15(1): 43-47.

10. Mazziotti G, Chiavistelli S, Giustina A (2015) Pituitary diseases and bone. Endocrinol Metab Clin N Am 44(1): 171-180.

11. MazziottiG, Mancini T, Mormando M, De Menis E, Bianchi A, et al. (2011) High prevalence of radiological vertebral fractures in women with prolactin-secreting pituitary adenomas. Pituitary 14(4): 299-306.

12. Mazziotti G, Porcelli T, Mormando M, De Menis E, Bianchi A, et al. (2011) Vertebral fractures in males with prolactinoma. Endocrine 39(3): 288293

13. Kaltsas G, Manetti L, Grossman AB (2002) Osteoporosis in Cushing's syndrome. Front Horm Res 30: 60-72.

14. Mancini T, Doga M, Mazziotti G, Giustina A (2004) Cushing's syndrome and bone. Pituitary 7(4): 249-252.

15. Minetto M, Reimondo G, Osella G (2004) Bone loss is more severe in primary adrenal than in pituitary -dependent Cushing's syndrome. Osteoporoz Int 15: 855-861.

16. Mirza F, Canalis E (2015) Secondary osteoporosis: pathophysiology and management. Eur J Endocrinol 173(3): 131-151.

17. Giustina A, Mazziotti G, Canalis E (2008) Growth hormone, insulin-like factors, and the skeleton. Endocr Rev 29(5): 535-569.

18. Madeira M, Neto LV, Torres CH, de Mendonça LM, Gadelha MR, et al. (2013) Vertebral fracture assessment in acromegaly. J Clin Denstom 16(2): 238-243.

19. Wassenaar MJ, Biermasz NR, Hamdy NA, Zillikens MC, van Meurs JB, et al. (2011) High prevalence of vertebral fractures despite normal bone mineral density in patients with long term-controlled acromegaly. Eur J Endocrinol 164(4): 475-483.

20. Anthony JR, Ioachimescu AG (2014) Acromegaly and bone disease. Curr Opin Endocrinol Diabetes Obes 21(6): 476-482.

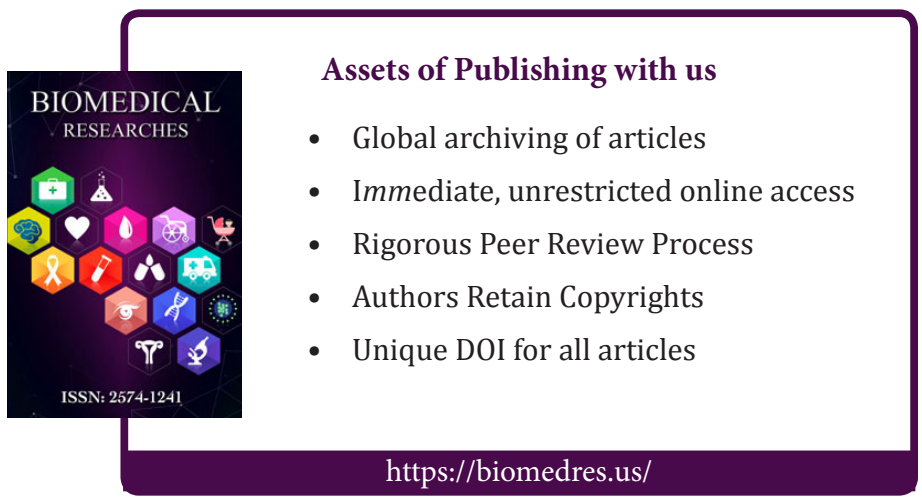

